\title{
Thermal comfort and draught assessment in a modern open office building in Tallinn
}

\author{
Martin Kiil ${ }^{1, *}$, Alo Mikola ${ }^{1}$, Martin Thalfeldt $^{1}$ and Jarek Kurnitski ${ }^{1,2}$ \\ ${ }^{1}$ Tallinn University of Technology, School of Engineering, Ehitajate tee 5, 19086 Tallinn, Estonia \\ ${ }^{2}$ Aalto University, School of Engineering, Rakentajanaukio 4 A, FI-02150 Espoo, Finland
}

\begin{abstract}
Modern office building users have high expectations about the working environment and thermal comfort, which requires the installation of complex technical systems such as combined cooling and ventilation. Room conditioning units of these systems must ensure temperature and ventilation control in a way that air velocity is low and the air temperature in acceptable range. Achieving air distribution avoiding draught is one of the key elements of a thermal comfort in modern office landscape. Higher air velocity in occupied zone is easily perceived as draught, which causes occupant dissatisfaction and complaints, as well as decrease in the productivity or effective floor space area. To reduce complaints, room air temperature setpoints or ventilation airflow rates are often modified, which may result in higher heating energy demand. In addition, excessive heating setpoint rise will not only consume more energy, but may cause health problems. Compared to cellular offices it is more difficult to ensure thermal comfort conditions in open office spaces where there are no walls for air flows. In addition, due to the higher number of employees it is more difficult to meet satisfactory conditions for everyone. The aim of this study was to evaluate thermal comfort parameters such as room air temperature, air speed and supply air temperature and how the users sense it in a modern office building in Tallinn, Estonia. Design room air temperature setpoints and air exchange rate were evaluated on open office spaces. Measured data with web-based indoor climate questionnaire was analysed. Results show which design and measured parameters make it possible to match the user comfort at all times.
\end{abstract}

\section{Introduction}

The concept of an open office started with the idea that it will improve collaboration between employees [1]. Nowadays, an open office is a fairly common solution that has been studied and found to have positive or negative effects. An open office solution can be very beneficial for the employer as it allows efficient floor space usage and thus cost savings [2]. In open office offices many people are working at the same time who have to deal with different work practices. Colleagues' activities and movements interfere with the work. Interfering noise sources are, for example, office equipment, telephone calls or communication with colleagues, which can lead to a significant loss of productivity. In addition to noise, there is a lack of space, low privacy and low job creation potential for specific concerns $[3,4]$.

Employees without partitions will lose their autonomy because lack of physical boundaries increases the likelihood of colleagues and managers interfering with work [5]. There is a wide range of positive and negative categories of open plan office design features [6], therefore this study concentrates mainly on thermal comfort (TC) and in particular to air velocity (AV) in the occupied zone.

TC is usually determined as too hot or too cold and has been found as a negative feature of open plan office design. Based on individuals the same indoor air temperature (IAT) refers to comfort and discomfort at the same time [7]. Therefore, it is useful to compare TC measurement results with employee awareness. Worldwide published indoor climate (IC) and human response study summaries can be found, for example, in REHVA GB No 62007 [8]. According to standard EN 15251, the use of class II of IC is justified in terms of productivity [9]. The IC, which affects health, comfort and productivity, is directly dependent on the energy use of the building. Ventilation rate and room temperatures in class II are also set to minimum energy efficiency requirements to avoid energy savings at the expense of the IC quality. The ventilation rate of the IC class I ventilation is higher, the AV and the IAT ranges are smaller compared to class II. With somewhat higher energy consumption, class I delivers maximum satisfaction and requires minimal IC complaints, while it has not been proven, that class I will

\footnotetext{
* Corresponding author: martin.kiil@taltech.ee
} 
significantly improve productivity. Niemelä claims that TC on the workers productivity can account for up to $55-75 \%$ of the overall life-cycle costs [10].

Wang confirmed that the higher the personvote number, the smaller the uncertainty of the results as 40 person-votes was proposed for the least adequate number for TC studies [11]. Taleghani indicated that the differences between different TC assessment method standards lies between upper and lower limits of the values [12]. Based on two case studies, Hens found that TC complaints could be more expected in summer period. Hens also refers that individuals interpret TC assessment scales differently which has an impact on the number of dissatisfied [13].

In this study we analysed a modern office building open office landscape built in 2016 to Ülemiste City business district in Tallinn. The ventilation systems of the building are divided by air handling units, taking the azimuth into account. Radiator system is designed for heating period. Exposed Halton CCE active cooling beam system through which the ventilation supply also works, maintain the cooling period IAT. According to the manager of the building, after the building has been put into operation, the IAT $\left(+21^{\circ} \mathrm{C}\right)$ has been gradually increased. The main complaints by tenants to the manager are IAT fluctuations and a draught of cold air in the work zone. To solve the complaints, the rooms are overheated $\left(>+25^{\circ} \mathrm{C}\right)$. To reduce draught, supply air temperature is higher $\left(+21^{\circ}\right)$ instead of design value $\left(+17^{\circ} \mathrm{C}\right)$. Heating energy costs increase as radiators switch out of heating mode and the room is switched to air heating mode by ventilation. We measured open office landscape air velocity rates and compared results with normative values and webbased IC questionnaire. Workplace-based AV measurements are less implemented compared to laboratory in general, but there have been no comprehensive measurements in Estonia.

\section{Methods}

This section explains the theoretical background, indices and on-site measurements implemented in this study. Three on-site measurements were carried out on the $1^{\text {st }}$ of March, $22^{\text {nd }}$ of May and $17^{\text {th }}$ of August in 2018 as heating-, mid- and cooling period cases. Measuring equipment is described in Table 1.

Table 1 Specifications of measuring equipment

\begin{tabular}{|c|c|c|c|c|c|c|}
\hline $\begin{array}{l}\text { Device / } \\
\text { Sensor }\end{array}$ & $\begin{array}{l}\text { Black globe } \\
\text { (LSI-Lastem) }\end{array}$ & $\begin{array}{l}\text { Anemometer (LSI- } \\
\text { Lastem) }\end{array}$ & $\begin{array}{l}\text { Thermo - } \\
\text { hygrometer (LSI- } \\
\text { Lastem) }\end{array}$ & $\begin{array}{l}\text { Controller } \\
\text { (EasyIO SH- } \\
\text { SMT131) } \\
\end{array}$ & $\begin{array}{l}\text { Anemometer } \\
\text { (Testo 435) }\end{array}$ & $\begin{array}{l}\text { Manometer } \\
\text { (Testo 510) }\end{array}$ \\
\hline Description & $\begin{array}{l}\text { Radiant } \\
\text { temperature } \\
\text { probe }\end{array}$ & Hot wire probe & $\begin{array}{l}\text { Temperature / } \\
\text { Relative humidity } \\
\text { probe }\end{array}$ & $\begin{array}{l}\text { Room } \\
\text { temperature }\end{array}$ & $\begin{array}{l}\text { Hot wire } \\
\text { probe }\end{array}$ & $\begin{array}{l}\text { Pressure } \\
\text { difference }\end{array}$ \\
\hline Image & & 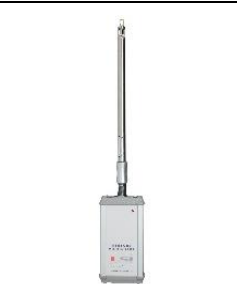 & 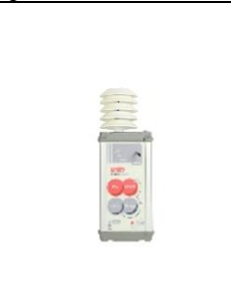 & $23^{1 / 2}$ & 8 & \\
\hline $\begin{array}{l}\text { Measuring } \\
\text { range }\end{array}$ & $-20 \ldots+60^{\circ} \mathrm{C}$ & $0,01 \ldots 20 \mathrm{~m} / \mathrm{s}$ & $\begin{array}{l}-20 \ldots+60^{\circ} \mathrm{C} \\
0 \ldots 100 \%\end{array}$ & $0 \ldots+50^{\circ} \mathrm{C}$ & $0 \ldots .20 \mathrm{~m} / \mathrm{s}$ & $0 \ldots 100 \mathrm{hPa}$ \\
\hline Resolution & $0,01^{\circ} \mathrm{C}$ & $0,01 \mathrm{~m} / \mathrm{s}$ & $\begin{array}{l}0,01^{\circ} \mathrm{C} \\
1 \%\end{array}$ & $0,1^{\circ} \mathrm{C}$ & $0,01 \mathrm{~m} / \mathrm{s}$ & $0,01 \mathrm{hPa}$ \\
\hline Accuracy & $0,15^{\circ} \mathrm{C}\left(0^{\circ} \mathrm{C}\right)$ & $\begin{array}{l}0 \ldots 0,5 \mathrm{~m} / \mathrm{s}=\mathrm{NA} \\
0,5 \ldots 1 \mathrm{~m} / \mathrm{s}= \\
\pm(0,05+0,05 \mathrm{Va}) \mathrm{m} / \mathrm{s} \\
>1 \mathrm{~m} / \mathrm{s}= \\
\pm(0,1+0,05 \mathrm{Va}) \mathrm{m} / \mathrm{s} \\
\left(+10 \ldots+30^{\circ} \mathrm{C}\right) \\
(1013 \mathrm{hPa})\end{array}$ & $\begin{array}{l}0,5^{\circ} \mathrm{C}\left(+5 \ldots+45^{\circ} \mathrm{C}\right) \\
1,8 \%(10 \ldots 90 \%)\end{array}$ & $0,1^{\circ} \mathrm{C}\left(+25^{\circ} \mathrm{C}\right)$ & $\begin{array}{l} \pm(0,03 \mathrm{~m} / \mathrm{s}+ \\
4 \% \text { of } \mathrm{mv})\end{array}$ & $\begin{array}{l} \pm 0,03 \mathrm{hPa} \\
(0 \ldots 0,3 \mathrm{hPa}) \\
0,05 \mathrm{hPa} \\
(0,31 \ldots 1,0 \\
\mathrm{hPa}) \\
\pm(0.1 \mathrm{hPa}+1.5 \% \\
\text { of } \mathrm{mv}) \\
(1.01 \ldots 100 \\
\mathrm{hPa})\end{array}$ \\
\hline
\end{tabular}

In addition, during first measurement we analysed air exchange rate and active chilled beams conditions prescribed according to building design materials. For year-round IAT evaluation we used building automatic system room controller data (Figure 1). We determined IAT, supply air temperature, air exchange rate and AV during both heating and cooling period. Measured values are compared with EN 15251 [9], Estonian energy efficiency minimum requirements for buildings regulation [14], IC draft regulation [15] (based mainly on previous two documents) and studied office building design materials. 


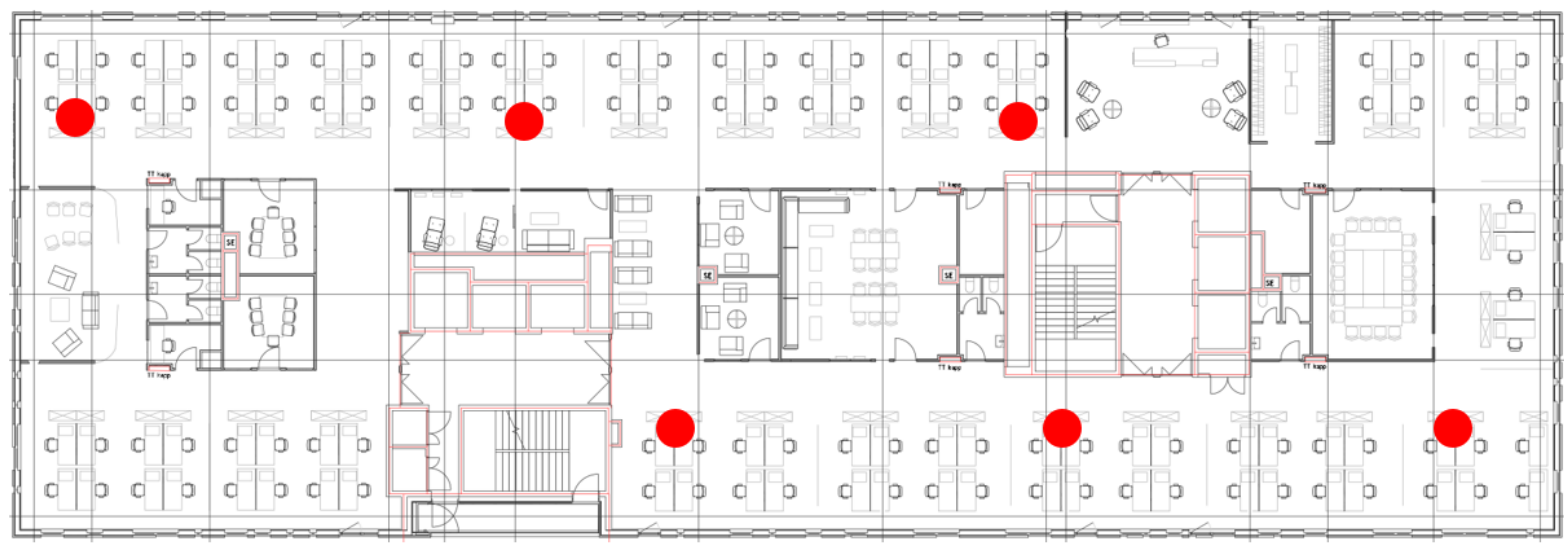

Figure 1 Year-around measure points for IAT controllers from north and south facade.

\subsection{Air velocity measurements}

We performed on-site measurements with a set of equipment from the manufacturer LSI-Lastem, which can be used to measure and calculate thermal IC parameters. According to ISO 7730 [16] we performed air velocity measurements at the height of $1,1 \mathrm{~m}$ (Figure 2) in different places around the building. We chose the spots according to main complaints from renters.
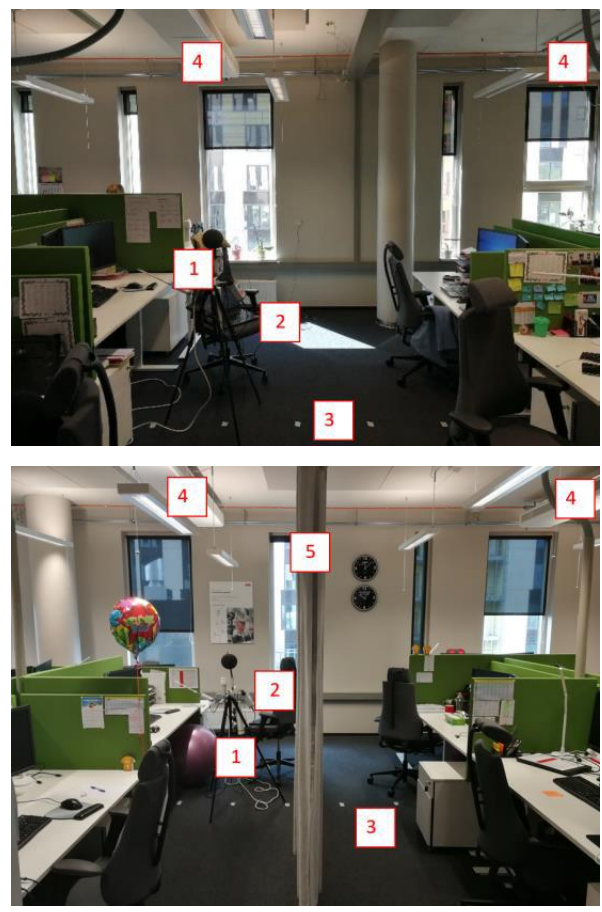

Figure 2 Air velocity measurements (1-probes; 2-hardware; 3-measureing area; 4-active chilled beam; 5-occupied zone dividing curtain).

To ensure the optimum measurement area we ran a smoke test on the first time to visualize and assess the air flow patterns. During measurements we fixed supply air velocity from the active cooling tab axis by $0,5 \mathrm{~m}$ step to $2,0 \mathrm{~m}$ as the length between two cooling units was $4,0 \mathrm{~m}$ (Figure 2 ).

During the first measurement we changed the position of diffuser slots (Halton Velocity Control) from closed (position $1=$ throttle) to open (position 3 = boost) [17] to determine the possible impact. During the third measurement we also studied the impact of the occupied zone dividing curtain (Figure 2).

\subsection{Indoor climate questionnaire}

We carried out IC questionnaire based on standard EN 15251 [9]. In agreement with the building manager we uploaded the survey to Google Forms with the access link which was sent to building users. Despite the expectations to get more responses than traditionally by paper questionnaires we got feedback from few over a 100 people of the total of 700-800 workers in the building.

\section{Results}

It is seen by the mean values of the reference points that the IAT remains higher on the southern façade within the $1^{\circ} \mathrm{C}$ range (

Figure 3$)$. In both zones, the IAT is higher than the minimum energy efficiency requirement $\left(+21^{\circ} \mathrm{C}\right)$ [14] throughout the year. The temperature above the recommended IAT is also confirmed in the southern zone during heating period by the setpoint midfield $\left(+20^{\circ} \mathrm{C} \ldots+24^{\circ} \mathrm{C}\right)[9]$. During cooling period, degrees over the recommended value $\left(+25^{\circ} \mathrm{C}\right)$ [14] are more seen on the south façade zone of the typical office floor. 

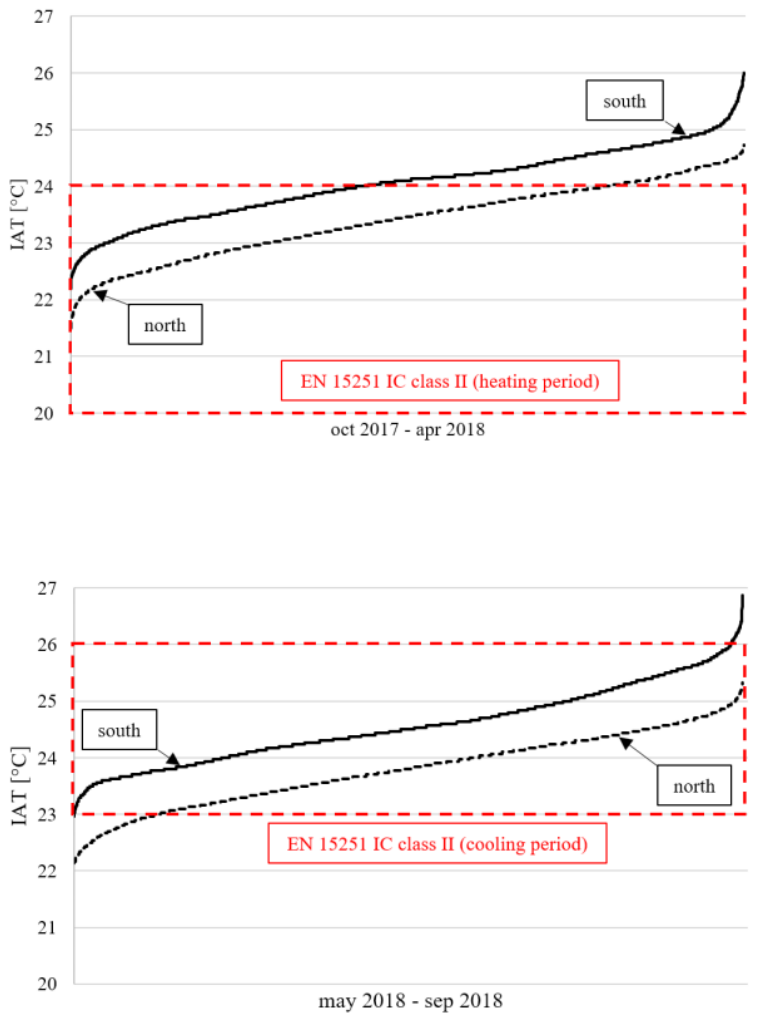

Figure 3 IAT duration curve during heating period (upper) and during cooling period (lower) on the north and south facade.

The higher IAT and supply air temperatures above recommended design values cause a situation in which the energy costs can increase as radiators are out of heating mode, switching heating of the rooms to ventilation air heating mode. Excessive temperature increase during the heating period may in addition to energy costs cause health problems. The temperature requirements, together with the design values and measured ones, are outlined below in Table 2 and Table 3.

Table 2 Measurements compared to normatives and design during heating period

\begin{tabular}{|l|l|l|l|l|l|}
\hline & $\begin{array}{l}\text { EN } \\
15251\end{array}$ & $\begin{array}{l}\text { Reg } \\
55\end{array}$ & $\begin{array}{l}\text { Reg IC } \\
\text { draft }\end{array}$ & Design & Measured \\
\hline $\begin{array}{l}\text { Indoor } \\
\text { air temp } \\
{\left[{ }^{\circ} \mathrm{C}\right]}\end{array}$ & +21 & +21 & $+20 \ldots+24$ & +21 & $+22,1 \ldots+23,2$ \\
\hline $\begin{array}{l}\text { Supply } \\
\text { air temp } \\
{\left[{ }^{\circ} \mathrm{C}\right]}\end{array}$ & - & - & - & +17 & $+19 \ldots+21$ \\
\hline $\begin{array}{l}\text { Air } \\
\text { exchange } \\
\text { rate } \\
{\left[1 /\left(\mathrm{s} \cdot \mathrm{m}^{2}\right)\right]}\end{array}$ & $1,5 \ldots 2,0$ & 2,0 & 1,6 & $0,5 \ldots 2,5$ & $\begin{array}{l}\text { Compliant to } \\
\text { design }\end{array}$ \\
\hline $\begin{array}{l}\text { Air } \\
\text { velocity } \\
{[\mathrm{m} / \mathrm{s}]}\end{array}$ & 0,16 & - & 0,16 & - & kuni 0,20 \\
\hline
\end{tabular}

ISO 7730 [16] category B seasonal values
Table 3 Measurements compared to normatives and design during cooling period

\begin{tabular}{|c|c|c|c|c|c|}
\hline & $\begin{array}{l}\text { EN } \\
15251 \\
\end{array}$ & $\begin{array}{l}\text { Reg } \\
55 \\
\end{array}$ & $\begin{array}{ll}\begin{array}{l}\text { Reg } \\
\text { draft }\end{array} & \text { IC } \\
\end{array}$ & Design & Measured \\
\hline $\begin{array}{l}\text { Indoor air } \\
\text { temp }\left[{ }^{\circ} \mathrm{C}\right]\end{array}$ & - & +25 & $+23 \ldots+26$ & $\begin{array}{l}+24 \\
\left(+25^{1}\right)\end{array}$ & $+24^{2}$ \\
\hline $\begin{array}{l}\text { Supply air } \\
\text { temp }\left[{ }^{\circ} \mathrm{C}\right]\end{array}$ & - & - & - & +17 & $\begin{array}{l}+20 \ldots+21 \\
\text { (beam } \\
+23 \ldots+24)\end{array}$ \\
\hline $\begin{array}{l}\text { Air } \\
\text { exchange } \\
\text { rate } \\
{\left[1 /\left(\mathrm{s} \cdot \mathrm{m}^{2}\right)\right]}\end{array}$ & $1,5 \ldots 2,0$ & 2,0 & 1,6 & $\begin{array}{l}0,5 \ldots \\
2,5\end{array}$ & $\begin{array}{l}\text { Compliant } \\
\text { to design }\end{array}$ \\
\hline $\begin{array}{l}\text { Air } \\
\text { velocity } \\
{[\mathrm{m} / \mathrm{s}]}\end{array}$ & $0,19^{3}$ & - & $0,19 / 0,25^{4}$ & - & $<0,08$ \\
\hline $\begin{array}{l}\text { design valu } \\
\text { measured I } \\
\text { ISO } 7730\end{array}$ & $\mathrm{n}$ ceiling $\mathrm{z}$ & he & $\begin{array}{l}\text { al } \\
\text { alues }\end{array}$ & & \\
\hline
\end{tabular}

Common indoor air temperature design value for heating period is $+21^{\circ} \mathrm{C}$ as standard [9] and minimum energy performance requirements [14] recommend. The building's heat loads were also calculated to a setpoint of $+21^{\circ} \mathrm{C}$. On the first measurement day in March the IAT was recorded at $+22,1^{\circ} \mathrm{C}$ to $+23,2^{\circ} \mathrm{C}$ in the measuring zones. This temperature corresponds to the requirements of Class II of the draft regulation on IC [15], which will soon be in place, between $+20^{\circ} \mathrm{C}$ and $+24^{\circ} \mathrm{C}$. One of the airflow's aim is designed to control the arrival of ventilation air in the occupied zone, so a 2-3 degrees lower temperature than the room air is widely used for the supply air. According to the project, the default value should be $+17^{\circ} \mathrm{C}$ for supply air, the optimum value would be between $+18^{\circ} \mathrm{C}$ and $+19^{\circ} \mathrm{C}$. For maintaining a high room air temperature and preventing draught effect the supply temperature is set between $+20^{\circ} \mathrm{C}$ and $+21^{\circ} \mathrm{C}$ values.

The setpoint for the IAT during the summer period is $+25^{\circ} \mathrm{C}$ according to the minimum energy efficiency requirements [14], the building's cooling loads are designed at $+24^{\circ} \mathrm{C}$ in the occupied zone and for the room ceiling at $+25^{\circ} \mathrm{C}$. On the day of the measurement in August, the indoor air temperature was measured at $+24^{\circ} \mathrm{C}$. This temperature corresponds to the requirements of Class II of the draft regulation on IC [15], between $+23^{\circ} \mathrm{C}$ and $+26^{\circ} \mathrm{C}$. According to the project, the default value is $+17^{\circ} \mathrm{C}$ for the supply air temperature, the setpoint of the ventilation unit was $+18^{\circ} \mathrm{C}$ and the cooling beam reached the air temperature between $+20^{\circ} \mathrm{C}$ and $+21^{\circ} \mathrm{C}$. The temperature of the air leaving the cooling beam was between $+23^{\circ} \mathrm{C}$ and $+24^{\circ} \mathrm{C}$.

Standard airflow on office spaces is 1,5 $1 /\left(\mathrm{s} \cdot \mathrm{m}^{2}\right)$ or $10 \mathrm{l} / \mathrm{s}$ per person [9]. In design practice the average value of $2,0 \mathrm{l} /\left(\mathrm{s} \cdot \mathrm{m}^{2}\right)$ is used. The same value is also the basis for energy efficiency minimum requirements for office buildings [14]. According to the specifics of the design and the use of space, the air exchange is divided between 0,5 and $2,51 /\left(\mathrm{s} \cdot \mathrm{m}^{2}\right)$ as 
the air flow we measured in the room elements of the ventilation system was post-design.

\subsection{Air velocity measurements}

For IC requirements, it is difficult to achieve low air velocity. Active cooling beams in combination with radiator heating are a common solution, but the speed of air movement remains at the level of the Class II IC, which in exploitation causes draught related complaints. As seen on Figure 2, obstacles are installed for air flow at the ceiling, such as cable trays, sprinkler systems or noise reduction elements for example. The impact to the airflow of these elements needs also further research. Draught rate calculated according to ISO 7730 [16] is under $10 \%$ during both heating and cooling period.

\subsubsection{Heating period}

During the initial measuring the supply air temperature was $+21^{\circ} \mathrm{C}$ and IAT was $+22^{\circ} \mathrm{C}$. The second measurement we lowered the supply temperature to $+19^{\circ} \mathrm{C}$ and with the lowered supply air temperature we also adjusted the diffuser slots to open position.

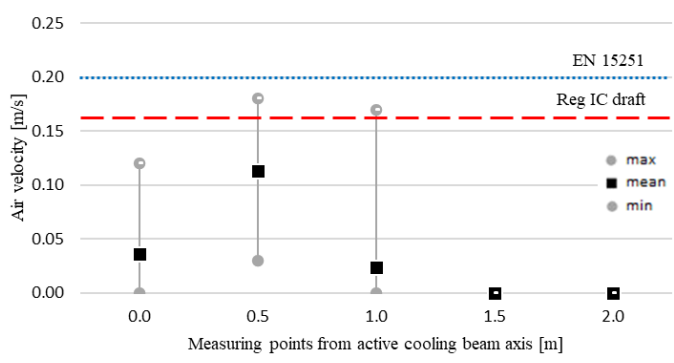

Figure 4 Air velocity measurements in initial situation during heating period.

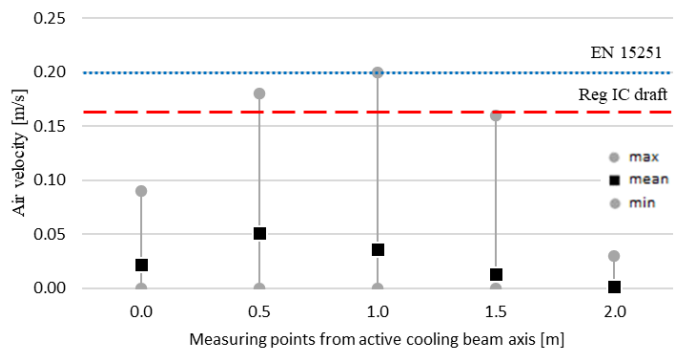

Figure 5 Air velocity after lowering supply air temperature by $2^{\circ} \mathrm{C}\left(+21^{\circ} \mathrm{C}\right.$ to $\left.+19^{\circ} \mathrm{C}\right)$.

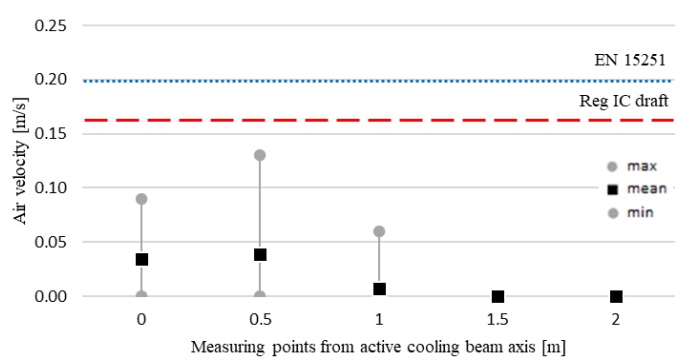

Figure 6 Air velocity after opening active cooling beam diffuser slots (Halton Velocity Control [17]).

The results shown on Figure 4, Figure 5 and Figure 6 illustrate that mean values of air velocity remain under the recommended values $[9,15]$. The figures include a standard air velocity limit value and the maximum air velocity of the draft IC regulation during the heating period according to Class II. When the supply air diffusers are opened, the air flow intensity decreases based on the measurement results. More intensive air speed second measurement parameters of the situation entered in the Halton selection tool [17] are shown on Figure 7.

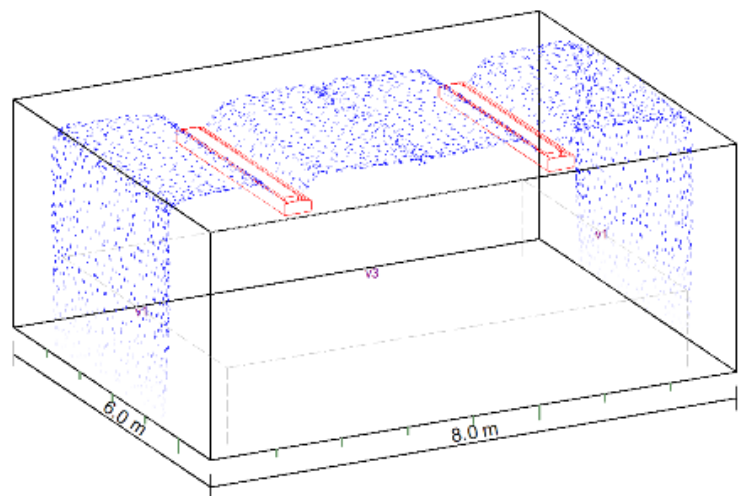

Figure 7 Isometric view of air flows from Halton HIT [17] according to heating period measurement, $\mathrm{v} 1=0,10 \mathrm{~m} / \mathrm{s}$, $\mathrm{v} 3=0,15 \mathrm{~m} / \mathrm{s}$ (lowered supply air temperature, supply air slot diffusers least open).

\subsubsection{Transitional period}

Opposite to complaints during transitional period measurement in May, we did not fix unacceptable air velocities as presented on Figure 8 and Figure 9. In draft IC regulation the cooling and non-cooling mode is separated as two limit values. The velocity of air movement at the points measured in the occupied zone is below the permitted limit. 


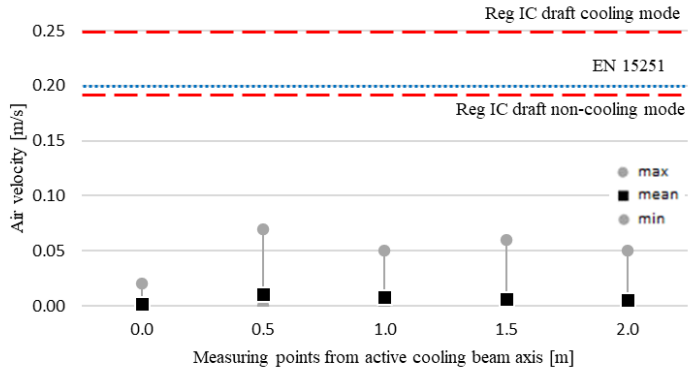

Figure 8 Air velocity in typical transitional period situation.

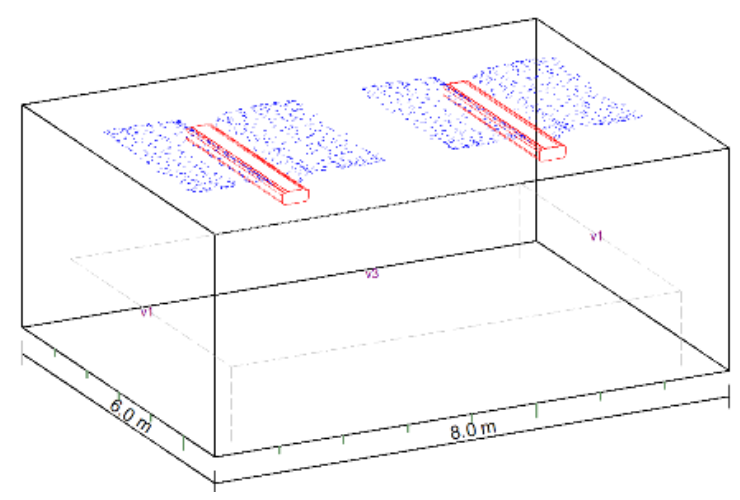

Figure 9 Isometric view of air flows from Halton HIT according to transitional period measurement, $\mathrm{v} 1=0,05 \mathrm{~m} / \mathrm{s}$, $\mathrm{v} 3=0,10 \mathrm{~m} / \mathrm{s}$.

\subsubsection{Cooling period}

During the third measurement in August for cooling period, again opposite to complaints we did not register unacceptable air velocities in the occupied zone. After lowering the IAT controllers from $+24,5^{\circ} \mathrm{C}$ to $+23,5^{\circ} \mathrm{C}$ larger velocities could be seen on Figure 10 and Figure 11. Homogenous active cooling beams create preconditions for workers to have acceptable IC if sitting out of the joined falling air flows. Moving desks from the axis of the cooling beams can lead to intensive draught effect.

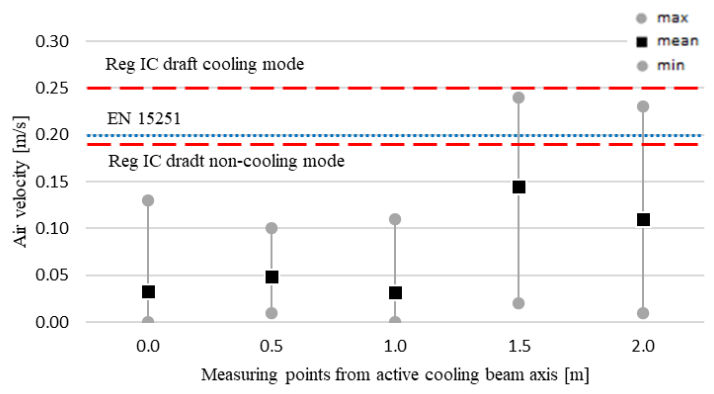

Figure 10 Air velocity in typical cooling period situation.

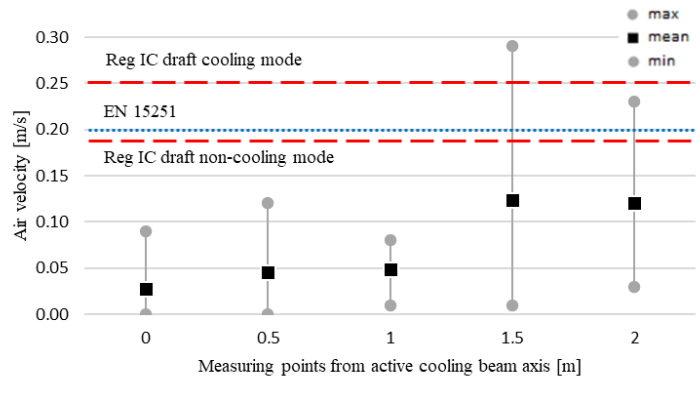

Figure 11 Air velocity in typical cooling period situation with occupied zone dividing curtain in position.

The results of the cooling period measurements show that the use of the dividing curtain affects the velocity of the air in the middle zone between the workstations. With or without a curtain the people sitting close to curtain have a higher risk for draught. Without curtain situation entered in the Halton selection tool [17] is shown on Figure 12.

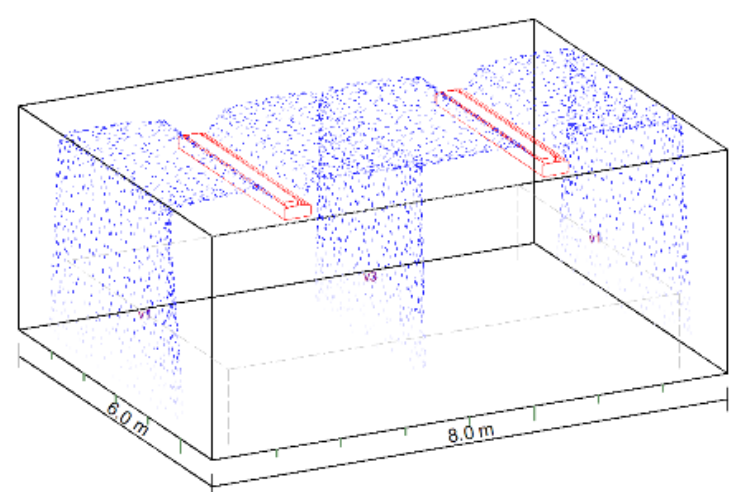

Figure 12 Isometric view of air flows from Halton HIT according to cooling period measurement, $\mathrm{v} 1=0,15 \mathrm{~m} / \mathrm{s}$, $\mathrm{v} 3=0,20 \mathrm{~m} / \mathrm{s}$ (without occupied zone dividing curtain in position).

\subsection{Indoor climate questionnaire}

Respondents complained frequently about cool air and unstable temperatures in the office, when one zone is warm and the other is cool. People were disturbed that the indoor temperature was not uniform throughout the year and fluctuated repeatedly. IAT was felt cooler, it was especially noticeable in NW zone where a third of the workers declared IAT to be lower than average. Overall thermal comfort feedback from respondents (Figure 13) comparing to Fanger's theoretical curve is shown of the Figure 14. 


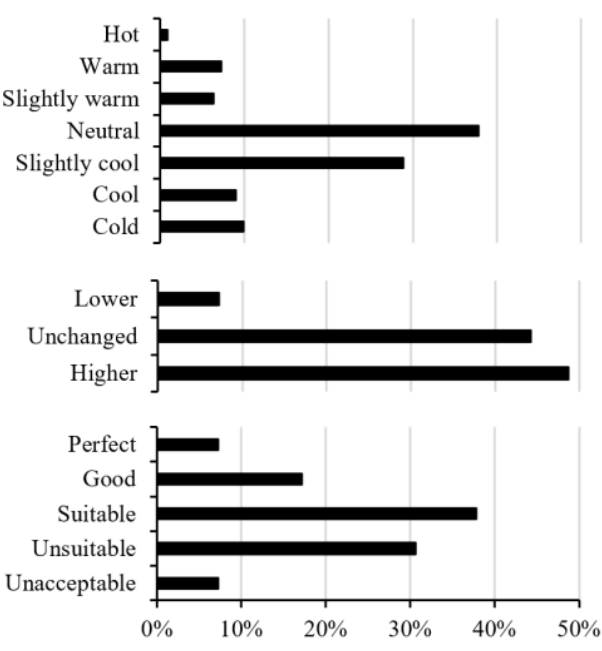

Figure 13 IAT results by IC questionnaire.

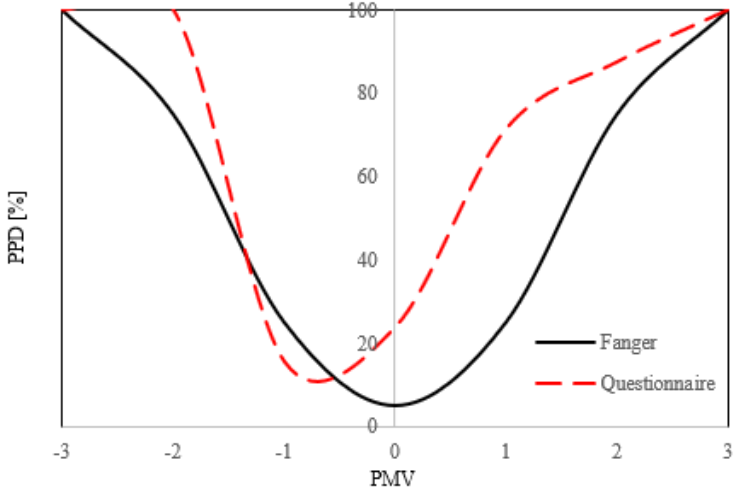

Figure 14 PPD (Predicted Percentage Dissatisfied) and PMV (Predicted Mean Vote index) by IC questionnaire compared to theoretical.

\section{Discussion and conclusions}

ICQ showed that IAT was felt cooler than the average. Higher IAT leads to higher heating energy costs mitigating the office workers complaints. High IAT during heating period contributes to lower relative humidity. In turn this contributes to dust formation and increases static electricity problems. In addition, too hot and dry air does not affect the health of workers well. Based on AV measurements, we can conclude that the inconvenience caused by the draught is increased by lowering the supply air temperature compared to the IAT. By adjusting the air nozzles of the active cooling beam, the AV can be adjusted to some extent. During the heating and transient period measurements, draught effect was not detected on the office landscape. During the cooling period, the risk of draught was detected in the case of intensive cooling mode. Higher Halton HIT AV values indicate that highest $\mathrm{AV}$ points where not located during $\mathrm{AV}$ measurements.

This study was based only on few measurements all in one office building. Further studies of human work environment need to be actively pursued and a number of work and learning spaces need to be studied for more in-depth conclusions. Thermal IC and the risk of draught are one of the key factors of ensuring employee satisfaction. Properly designed and functioning technical systems help to ensure productivity, wellbeing and comfort. We claim that monitoring and periodic analysis of the IC is essential for the developer and building manager to ensure maximum satisfaction of the tenant or the visitor.

This research was supported by the Estonian Centre of Excellence in Zero Energy and Resource Efficient Smart Buildings and Districts, ZEBE, grant 2014-2020.4.01.150016 funded by the European Regional Development Fund. The authors are grateful for the valuable help from Katrin Sulg (AS Mainor Content Manager for Services) and Taltech Energy Efficiency of Buildings graduate students Dagmar Teppe, Anastassia Tretjak and Andrei Engels.

\section{References}

1. R. G. Geen ja J. J. Gange, Psychol Bull 84, 6 (1977)

2. M. S. Sanders ja E. J. McCormick (1993)

3. P. Leather, D. Beale ja L. Sullivan, J Environ Psychol 23, 2 (2003)

4. T. L. Smith-Jackson ja K. W. Klein, J Environ Psychol 29, 2 (2009)

5. J. Pejtersen, L. Allermann, T. S. Kristensen ja O. M. Poulsen, Indoor Air 16, 5 (2006)

6. A. Shafaghat, A. Keyvanfar, M. S. Ferwati ja T. Alizadeh, Sustain. Cities Soc 19 (2015)

7. I. Balazova, G. Clausen ja D. P. Wyon, Proceedings of Clima 2007 (2017)

8. P. Wargocki, O. Seppänen, A. Boestra, D. Clements-Croome, K. Fitzner ja S. O. Hanssen, REHVA (2007)

9. CEN/TC 156, EN 15251:2007, CEN (2007)

10. T. Niemelä, K. Levy, R. Kosonen ja J. Jokisalo, Sustain. Cities Soc 32 (2017)

11. J. Wang, Z. Wang, R. de Dear, M. Luo, A. Ghahramani ja B. Lin, Energ Buildings 181 (2018)

12. M. Taleghani, M. Tenpierik, S. Kurvers ja A. van den Dobbelsteen, Renew Sust Energ Rev 26 (2013)

13. H. S. Hens, Build Environ 44, 7 (2009)

14. Ministry of Economics Affairs and Communication, Regulation nr 55, State Gazette (2015)

15. Ministry of Economics Affairs and Communication, Draft Requirements for building indoor climate, State Gazette (2018)

16. ISO/TC 159, ISO 7730:2005, ISO (2005)

17. Halton HIT Design, Halton Oy (2018) 